\title{
Physicochemical property of oil palm leaves and utilization of cellulose microfiber as probiotic encapsulant
}

\author{
USMAN PATO $^{1, \boldsymbol{v}}$, DEWI FORTUNA AYU ${ }^{1}$, EMMA RIFTYAN $^{1}$, FAJAR RESTUHADI ${ }^{1}$, \\ WASISSO TUNGGUL PAWENANG ${ }^{1}$, ROYYAN FIRDAUS $^{1}$, ANNISA RAHMA ${ }^{1}$, \\ INGRID SURYANTI SURONO ${ }^{2}$, IRWANDI JASWIR ${ }^{3}$ \\ ${ }^{1}$ Department of Agricultural Technology, Faculty of Agriculture, Universitas Riau. Jl. H.R. Soebrantas Km. 12,5, Simpang Baru, Pekanbaru 28293, Riau, \\ Indonesia. Tel.: +62-761-63270, Fax.: +62-761-63271, "email: usmanpato@yahoo.com \\ ${ }^{2}$ Department of Food Technology, Faculty of Engineering, Universitas Bina Nusantara. Jl. K.H. Syahdan No. 9, Kemanggisan, Palmerah, Jakarta Barat \\ 11480, Jakarta, Indonesia \\ ${ }^{3}$ International Institute for Halal Research and Training, Internasional Islamic University Malaysia. Jl. Gombak, 53100 Selangor, Malaysia
}

Manuscript received: 26 May 2021. Revision accepted: 26 June 2021

\begin{abstract}
Pato U, Ayu DF, Riftyan E, Restuhadi F, Pawenang WT, Firdaus R, Rahma A, Surono IS, Jaswir I. 2021. Physicochemical property of oil palm leaves and utilization of cellulose microfiber as probiotic encapsulant. Biodiversitas 22: 2937-2944. The vast land of oil palm (Elaeis guineensis) in Indonesia has a huge potential for oil palm solid waste, which can be used for various human needs. The physiochemical analysis performed was proximate analysis and fiber content, FTIR and X-ray diffraction analysis, an in vitro test on viability and resistance to acid and bile during storage at room and refrigerated temperatures. The main content of oil palm leaves was carbohydrates, especially fiber and followed by ash, protein, and fat. Fiber from oil palm leaves is mainly composed of lignin followed by cellulose and hemicellulose. X-ray diffraction analysis showed that the crystal index of cellulose from oil palm leaves was $10.1 \%$. FTIR analysis showed that the enormous absorption value, which was the stretching vibrations of the -OH group ranging from 2919.17 to $2914.82 \mathrm{~cm}^{-1}$. Cellulose microfiber from oil palm leaves maintained the viability of L. fermentum InaCC B 1295 for up to 28 $\mathrm{d}$ of storage at room and refrigerated temperatures. The survival of strain B1295 at low pH and presence of bile was very high, characterized by a decrease in the number of cells by less than $0.5 \log \mathrm{CFU} / \mathrm{mL}$ during storage of $35 \mathrm{~d}$ at room and refrigerated temperatures. Therefore, Cellulose microfiber from oil palm leaves has the potential to be used as an encapsulant for probiotics.
\end{abstract}

Keywords: Cellulose, CMF, oil palm leaves, physicochemical properties, probiotic

\section{INTRODUCTION}

Oil palm (Elaeis guineensis) is among the best known and most extensively cultivated plant families, especially in Indonesia and Malaysia. Many standard products and foods are derived from oil palm, making them one of the most economically important plants. Indonesia is the largest palm oil-producing country globally, with an area of $14,724,600$ ha and a CPO production of 45.8 million tonnes in 2019. With a vast oil palm plantation, the potential for palm oil waste is also very abundant, namely empty fruit bunch, oil palm trunk, oil palm frond, and oil palm leavess. The report shows that for one oil palm tree that is already producing, only $10 \%$ of oil will be produced, and the remaining $90 \%$ is biomass in the form of trunk, frond, leaves, empty fruit bunches, and palm oil shells (Abdullah and Sulaim 2013). Oil palm biomass waste has shown the potentiality of producing various types of value-added products such as medium density panels, blockboard, laminated veneer lumber, mineral-bonded particleboard, plywood, chipboard, and chipboard thermoset and thermoplastic composites, nanocomposites, pulp, and paper manufacturing. Conversion oil palm trunk can be converted into plywood, particleboard, and rubberwood (Khalil et al. 2010; Dungani et al. 2013).
In Indonesia, oil palm leaves (OPL) has been used as raw material for making animal feed and compost (Rizali et al. 2018; Daryono and Alkas 2017). However, OPL also can be used as raw material for making cellulose microfiber (CMF) because they contain a lot of cellulose. Cellulose microfiber (CMF), also called microfibrillated cellulose, is cellulose that undergoes fiber separation treatment into microfibrils with a diameter range of 10-100 $\mathrm{nm}$ and a length of several micrometers. In addition, CMF has characteristics, including specific surface area, high strength, and stiffness, low weight, biodegradable and renewable properties (Risnasari et al. 2012). These characteristics make cellulose microfibrils have good mechanical properties, so they have the potential to be used in the composite, automotive, pulp and paper, electronics, paint and coatings industries, films, papermaking additives, thickening agents for food and cosmetic products, and various medical applications (Fahma et al. 2010; ChingaCarrasco 2011; Lavoine et al. 2012).

In the food industry, $\mathrm{CMF}$ can be used as an encapsulation material for probiotic and bioactive compounds in food. Encapsulation is aimed at maintaining probiotic viability with a minimum amount of $10^{7} \log$ $\mathrm{CFU} / \mathrm{mL}$ when it passes through the digestive tract to perform its therapeutic function (Sarvari et al. 2014; Abbasiliasi et al. 2017). The encapsulant materials can be 
selected from a variety of natural and synthetic polymers, such as carbohydrates in the form of starch, dextrins, pectins, sucrose, cellulose, chitosan, alginates, and carrageenan, while lipids are in the form of wax, paraffin, monoglycerides, and diglycerides, as well as proteins in the form of milk, gluten, casein., gelatin, and albumin (Ayoub et al. 2019; de la Cruz Pech-Canul et al. 2020). Encapsulation with different encapsulating materials has successfully been shown to protect probiotic bacteria in many fermented dairy products (Abghari et al. 2011). Probiotics' viability in all food products is affected by many intrinsic and extrinsic aspects such as oxygen, post acidification in fermented products, $\mathrm{pH}$, storage temperature, production of hydrogen peroxide, and processing conditions (Tripathi and Giri 2014). The purposes of the present study were to characterize the physic-chemical properties of cellulose from OPL as raw material for cellulose microfiber and to evaluate the hydrogel $\mathrm{CMF}$ as an encapsulant on the viability and probiotic properties of Lactobacillus fermentum InaCC B1295 during storage at room and refrigerated temperatures.

\section{MATERIALS AND METHODS}

\section{Study area}

The study was conducted in the Laboratory of Agricultural Product Analysis, Faculty of Agriculture, Universitas Riau, Pekanbaru City, Riau Province, Indonesia $\left(0^{\circ} 25^{\prime}-0^{\circ} 45^{\prime} \mathrm{N}\right.$ and $\left.101^{\circ} 14^{\prime}-101^{\circ} 34^{\prime} \mathrm{E}\right)$.

\section{Physicochemical property of oil palm leaves, cellulose and cellulose microfiber \\ Raw materials}

The materials used in this research were solid waste such as OPL and OPF, from palm oil variety Tenera were obtained by PT. Multi Plasma Sejahtera, Bandar Sikijang District, Pelalawan Regency, Riau Province.

\section{Characterization of oil palm solid waste}

Characterization of OPL and OPF included analysis of moisture, ash, and fiber content (Gravimetric method), protein content (Kjeldahl method), fat content (Soxhlet method), and carbohydrates are calculated by difference (AOAC, 2012). In addition, hemicellulose, lignin, and cellulose contents were analyzed according to Jung et al. (2015).

\section{Isolation of cellulose}

Cellulose was isolated using the same method as Fahma et al. (Fahma et al. 2010). The OPL and OPF were cut to $0.5-1 \mathrm{~cm}$ length before they were exposed to any treatment. Hemicellulose was extracted by bleaching the fibers with 6 wt $\% \mathrm{KOH}$ solution for $12 \mathrm{~h}$ and rinsing with deionized water until $\mathrm{pH} 7$. Next, the extracted fibers were soaked $\mathrm{NaClO}_{2}$ solution under acidic conditions ( $\mathrm{pH} 4-5$ ) for $5 \mathrm{~h}$, then washed with deionized water to remove lignin. The resulting cellulose fibers were stored in a refrigerator before further analysis.

\section{FTIR analysis}

Cellulose was characterized using an FTIR spectrometer to study the chemical composition and bonding present. The FTIR spectra of cellulose samples were recorded using the Thermo Nicolet Nexus FTIR spectrometer coupled with an ATR detector (Thermo Scientific Nicolet iS10). All spectra were recorded in the spectral range $7800-350 \mathrm{~cm}^{-1}$ at $4 \mathrm{~cm}^{-1}$ with 32 scans. Analysis of the spectral data was performed by using OMNIC version 6.0 (Thermo Scientific Nicolet) software.

\section{$X$-ray diffraction analysis}

XRD analyzes were carried out to determine the molecular groups and degree of crystallinity in cellulose. XRD testing used the X'Pert PRO PANalytical instrument machine. The XRD test conditions used $\mathrm{CuK} \alpha$ radiation with a wavelength $(\lambda=0.154)$. The power and current used in the XRD test are $40 \mathrm{kV}$ and $30 \mathrm{~mA}$. The diffraction rate ranges from $5^{\circ}$ to $50^{\circ}$, with an increment rate of $2 \theta-0.02^{\circ}$. The crystallinity index (Ic) of the biocomposite film was calculated according to the following formula:

$$
\mathrm{Ic}=[(\mathrm{I} 002-\mathrm{I} \mathrm{am}) / \mathrm{I002}] \times 100
$$

Where: I002 is a diffraction intensity of $2 \theta-22.6^{\circ}$ which indicates the crystalline region of the material. Iam is the diffraction intensity $2 \theta-18^{\circ}$ which indicates the amorphous region of the material (Yasim-Anuar et al. 2017).

\section{Preparation of cellulose microfiber}

The preparation of CMF was carried out using the Lestari method (2016). First, OPL was cut into small pieces with a length of $0.5-1 \mathrm{~cm}$, then washed with water, then boiled in boiling water $\left(100^{\circ} \mathrm{C}\right)$ for $1 \mathrm{~h}$ which they were filtered. The OPL that has been boiled was then washed with water until clean, then dried in an oven at $60^{\circ} \mathrm{C}$ for 4 h. Next, the dry fiber was put into a beaker, $1000 \mathrm{~mL}$ of $6 \%$ $\mathrm{KOH}$ was added then soaked at room temperature for $12 \mathrm{~h}$. After that, the fibers are washed with water for three rinses. Furthermore, the washed fibers are soaked using a hypochlorite solution for $5 \mathrm{~h}$, and then the empty bunches are filtered and washed with water to a neutral $\mathrm{pH}(\mathrm{pH} 7)$. Furthermore, OPL was dried and mashed in a blender until smooth, then filtered using an 80 mesh sieve. Finally, the cellulose flour of OPL was sent to Nano Center Indonesia, Tangerang Banten, Indonesia, to be processed into cellulose microfiber (CMF). CMF was processed by milling the cellulose flour using a Planetary Ball Mill machine at a speed of 8,000 rpm for 60 min with a run time of $15 \mathrm{sec}$ and a rest time of $2 \mathrm{~min}$ to avoid sample damage caused by heat during milling. The results of the milling were then sieved to obtain CMF.

\section{Viability, acid and bile resistance of Lactobacillus fermentum InaCC B1295 \\ Preparation of MRS Broth medium}

Preparation of MRS broth (MRB) medium was carried out by weighing $13.78 \mathrm{~g}$ of MRSB put in a beaker glass and dissolved with distilled water to a volume of $250 \mathrm{~mL}$. The solution was distributed into test tubes, with each test tube containing $5 \mathrm{~mL}$ and closed using a setup. Then put in 
an autoclave to be sterilized at a temperature of $121^{\circ} \mathrm{C}$, at 1 atm for $15 \mathrm{~min}$. Finally, the MRSB medium is ready to be used.

\section{Preparation of MRS Agar medium}

Preparation of MRS agar (MRSA) medium was carried out by weighing $68.2 \mathrm{~g}$ of MRSA, and then it was put into Erlenmeyer and dissolved with distilled water to a volume of $1000 \mathrm{~mL}$ and stirred. Next, the media was heated on a hot plate and stirred using a magnetic stirrer until homogeneous. Furthermore, sterilization was carried out by autoclave at a temperature of $121^{\circ} \mathrm{C}, 1$ atm for $15 \mathrm{~min}$. Finally, the homogeneous MRS agar solution was poured into $\pm 15 \mathrm{~mL}$ sterilized Petri dishes. The pouring of the media is carried out in laminar airflow. Then the petri dish containing the media is closed and allowed to solidify.

\section{Activation of Lactobacillus fermentum InaCC B1295 culture}

The Lactobacillus fermentum InaCC B1295 culture was activated by inoculating one loop needle into a test tube containing $5 \mathrm{~mL}$ MRSB medium and then stirring with vortex. Media was then incubated at $37^{\circ} \mathrm{C}$ for $24 \mathrm{~h}$ in an incubator so that the active culture stock was obtained, marked by a change in the color of media to become cloudy. The active cultures were stored in the refrigerator and ready to use.

\section{Separation of cells and supernatant}

The active culture of L. fermentum InaCC B1295 was separated between cells and supernatant by centrifuge at $4500 \mathrm{rpm}$ for $15 \mathrm{~min}$. First, the supernatant is discarded, then the cells are washed 2 times using sterile distilled water until clean cells are obtained. Then the cells are removed plus a phosphate buffer with a ratio of $1: 1(\mathrm{w} / \mathrm{v})$, then put in a clean container and stored at $4{ }^{\circ} \mathrm{C}$ refrigerators.

\section{Preparation of sterile microfiber cellulose hydrogel}

A sterile CMF hydrogel was prepared by first making 8\% polyvinyl alcohol (PVA). Weighed $96 \mathrm{~g}$ of PVA, then added $1104 \mathrm{~mL}$ of distilled water and then heated until dissolved at $100^{\circ} \mathrm{C}$ using a magnetic stirrer hot stirrer. The PVA solution was allowed to cool at room temperature. After that, $8 \%$ PVA was mixed with and CMF by inserting $250 \mathrm{~g}$ of CMF in $250 \mathrm{~mL}$ of PVA, then heating it with a hot plate magnetic stirrer assisted until the CMF dissolved utterly to form a CMF hydrogel. Then the CMF hydrogel was measured for $\mathrm{pH}$ and viscosity with a $\mathrm{pH}$ meter and viscometer, then sterilized by autoclave at $121^{\circ} \mathrm{C}$ with $1 \mathrm{~atm}$ pressure for $15 \mathrm{~min}$. The sterile CMF hydrogel is cooled and ready for use as a lactic acid bacteria (LAB) encapsulant (Fung et al. 2011).

\section{Preparation of encapsulated lactic acid bacteria}

The preparation of encapsulated LAB was carried out according to Yasim-Anuar et al. (2017) with minor modifications. First, the encapsulation process is carried out by adding $40 \mathrm{~mL}$ of cell biomass to $40 \mathrm{~mL}$ of sterile CMF hydrogel, then stirring using a stirring rod until well blended. The encapsulated LAB was then tested for its probiotic properties.

\section{Treatment at various temperatures and storage time}

Storage was carried out by inserting $2 \mathrm{~mL}$ of each of the encapsulated LAB into $5 \mathrm{~mL}$ cryovial, then stored at room temperature and refrigerated temperature $\left(4^{\circ} \mathrm{C}\right)$ for $0,7,14$, 21, 28 and $35 \mathrm{~d}$. Then the encapsulated LAB was tested for its viability according to Pato et al. (2020) and resistance to acid and bile, according to Pato (2003) and Nuraida et al. (2012).

\section{RESULTS AND DISCUSSION}

\section{Physicochemical property of oil palm leaves, cellulose and cellulose microfiber}

Flours derived from whole dried OPL and dried cellulose of OPL were shown in Figure 1. Flour derived from cellulose of OPL was generally light brown, and flour from the whole OPL was dark green because it still contained chlorophyll which was not fully damaged during leaf drying. However, after being processed into cellulose flour, the color changed to light brown. This change was because OPL was immersed in a $6 \% \mathrm{KOH}$ solution then soaked again in hypochlorite solution to obtain cellulose. Sodium hypochlorite solution is a compound used for the bleaching process that removes chlorophyll, the green pigment in OPL (Muneer et al. 2014).

OPL is mainly composed of carbohydrates, especially crude fiber, followed by protein, water, fat, and ash (Table 1). Nurhaita and Ruswendi (2007) reported several components in OPL, such as $8.51 \%$ protein and $28.48 \%$ crude fiber. The crude fiber content in our study was much higher than that reported by Hurhaita, possibly because, in our study, we did not separate the leaf sticks containing high crude fiber and analyzed with the leaves. OPL is also rich in minerals, especially $\mathrm{Ca}$ and $\mathrm{Mg}$, which cause the ash content to be higher than OPL. In order to make CMF, it is necessary to know the fiber content in OPL, and the result was shown in Table 2.

Table 1. Chemical composition of OPL

\begin{tabular}{lc}
\hline Chemical compounds & Amount $(\boldsymbol{\%})$ \\
\hline Water & 7.75 \\
Ash & 4.41 \\
Fat & 5.36 \\
Protein & 9.93 \\
Crude fiber & 43.01 \\
Carbohydrate & 29.54 \\
\hline
\end{tabular}

Table 2. Cellulose, hemicellulose, and lignin content from OPL

\begin{tabular}{lc}
\hline Components & Amount (\%) \\
\hline Cellulose & 43.2 \\
Hemicellulose & 5.2 \\
Lignin & 51.6 \\
\hline
\end{tabular}




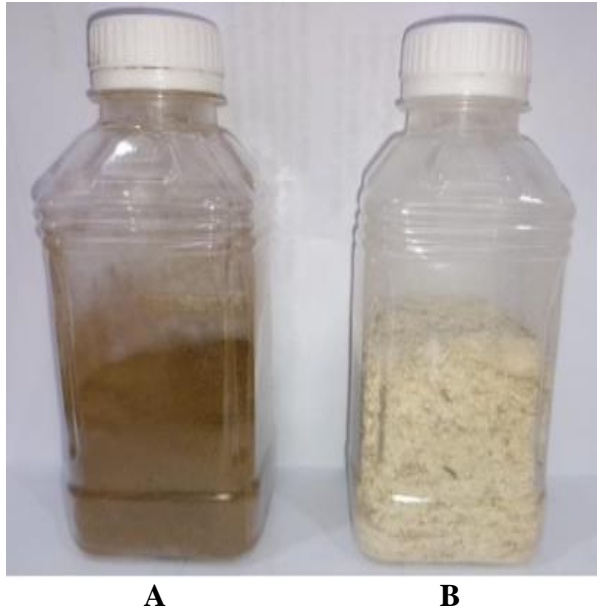

Figure 1. Flours derived from whole dried OPL (A) and flours from the dried fiber from OPL (B)

The main content in OPL fiber is lignin, followed by cellulose and hemicellulose. Lignin is a substance found in vascular plants, usually within the cell walls and between cells. Rosli et al. (2017) have reported moisture content of $9.51 \%$ and lignin $27.7 \%$, whereas, in this study, it was found that moisture content was $8.24 \%$ and lignin $23.2 \%$ in the OPEFB. Lignin is primarily a supportive structure and is part of the secondary thickening of tall plants. This fact is why the amount of lignin in the stem is more than other parts of a plant to support it so that it stands firm and strong and does not collapse easily (Shadle et al. 2002).

The cellulose isolated from OPL was then analyzed for crystallinity using X-Ray Diffraction (XRD), and the results can be seen in Figure 2. XRD pattern of OPL celluloses has seven diffraction peaks at $2 \theta=15^{\circ}, 17^{\circ}, 22^{\circ}$, $34^{\circ}, 42^{\circ}, 43^{\circ}$ and $72^{\circ}$. The XRD diffractogram of cellulose nanofiber from oil palm mesocarp fiber showed intense reflection at $2 \theta=21$ to $22^{\circ}$, and other small peaks at $2 \theta=$
18 to $19^{\circ}$ and 35 to $42^{\circ}$ (Yasim-Anuar et al. 2018). Crystallinity analysis using X-Ray Diffraction (XRD) was also performed to determine the degree of crystallinity in the cellulose sample (Table 3 ).

According to Gümüskaya et al. (2003), the degree of crystallinity is the essential parameter in a crystalline structure. The higher the value of the degree of crystallinity, the stronger the rigidity of fiber. The degree of crystallinity of OPL of $10,1 \%$ was lower than that of oil palm empty fruit bunch at $58.1 \%$ (Lestari 2016).

FTIR spectroscopy is an analytical method used for polymer material characterization and functional group analysis. By determining and recording the residual spectra results with energy absorption by organic molecules in infrared light. Infrared is defined as an area having a wavelength of $1-500 \mathrm{~cm}^{-1}$. The results of FTIR analysis of cellulose from OPL are presented in Figure 3.

It can be seen that the dominant absorption peak which was the stretching vibrations of the - $\mathrm{OH}$ group on the cellulose in OPL at $3419.71 \mathrm{~cm}^{-1}$. The same finding was found in the cellulose of oil palm empty fruit bunch (Fahma et al. 2010). The next absorption peak was $\mathrm{CH}$ stretching in OPL at $2902.28 \mathrm{~cm}^{-1}$. The small peaks with sizes between $1637.01-$ $1637.49 \mathrm{~cm}^{-1}$ in OPL-cellulose were characteristic of the carbonyl groups in hemicellulose or lignin. The peak with a size of $1427.43-1055.32 \mathrm{~cm}^{-1}$ is thought to be a C-C aromatic loop of bound lignin or $\mathrm{C}-\mathrm{H}$ and $\mathrm{C}-\mathrm{O}$ ester bonds stretching vibration from the partial acetylation process of the hydroxyl group of carbohydrates and lignin residues (Sun et al. 2000).

Table 3 Crystal index of cellulose from OPL

\begin{tabular}{lc}
\hline & Value \\
\hline $\mathrm{I}_{002}$ & 88.41 \\
$\mathrm{I}_{\mathrm{AM}}$ & 79.45 \\
Crystal index $(\%)$ & 10.1 \\
\hline
\end{tabular}

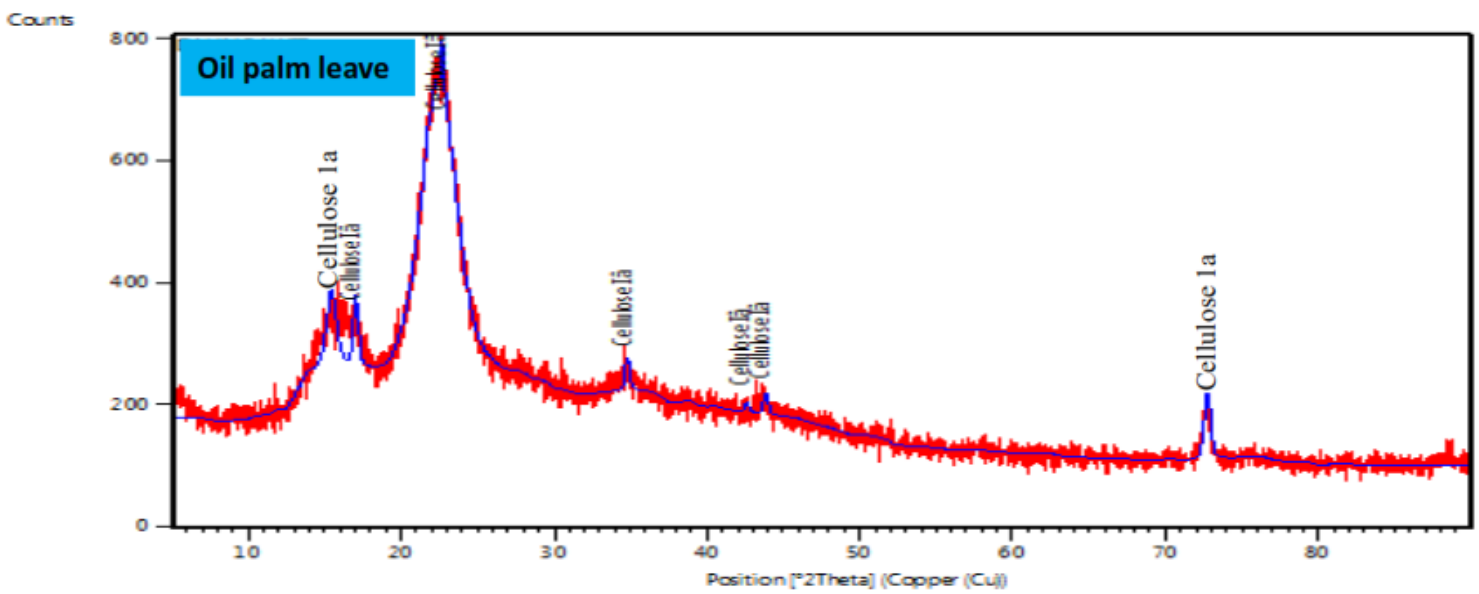

Figure 2. XRD diffractogram of cellulose of OPL 


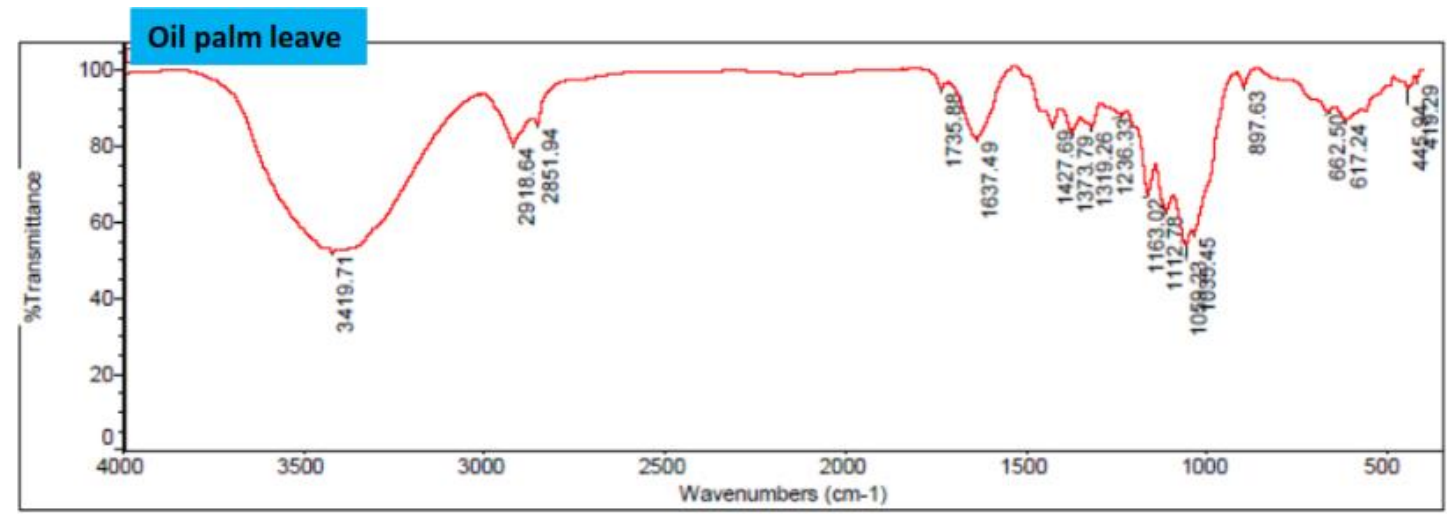

Figure 3. FTIR spectra of cellulose from OPL

\section{Viability, acid and bile resistance of Lactobacillus fermentum InaCC B1295}

Viability is one of the requirements for probiotics to be able to perform their therapeutic function when consumed. Analysis of variance showed that storage time significantly affected ( $\mathrm{P}>0.05) \mathrm{LAB}$ viability, but storage temperature did not significantly influence $(\mathrm{P}<0.05)$ LAB viability (Table 4).

The decrease in the amount of LAB occurred at both storage temperatures from 7 to $35 \mathrm{~d}$ encapsulated with CMF hydrogel from OPL. However, the most significant decrease occurred at room temperature of $7.37 \mathrm{log}$ $\mathrm{CFU} / \mathrm{mL}$, while at temperature, the decrease was only 4.72 $\log \mathrm{CFU} / \mathrm{mL}$. This fact is because the longer the storage time, the CMF hydrogel layer covering the bacterial cells has decreased its stability due to the increased humidity in the CMF hydrogel as the length of storage increases. CMF hydrogel, which has increased humidity, will reduce its tensile strength and flexibility, causing the gel bond to stretch, and bacteria quickly get out of the coating so that the bacteria come into direct contact with temperature, which causes cell damage and affects bacterial growth This statement follows Sianturi (2018), which stated that the robustness of hydrogels containing PVA depends on humidity. The higher the humidity, the more water is absorbed, reducing tensile strength and flexibility.

The results of this study are in line with Bilang et al. (2018), which states that the robustness of the encapsulant matrix formed will decrease with increasing storage time. The CMF hydrogel from OPL maintained LAB viability at both storage temperature conditions for $28 \mathrm{~d}$. The viability of LAB using CMF hydrogels in the study was much longer than the finding reported by Fung et al. (2011) that the viability of $L$. acidophilus encapsulated with a hydrogel of cellulose nanofiber (CNF) from okra lasted for only $5 \mathrm{~d}$, CNF oil palm trunk for $5 \mathrm{~d}$ and CNF oil palm frond for 21 d. Different results were reported by Hossain et al. (2021) that probiotics encapsulated using a mixture of cocoa powder with Na-alginate or FOS retained viability of more than $10^{7} \mathrm{CFU} / \mathrm{g}$ for up to 180 and $120 \mathrm{~d}$ of storage at 4 and $25^{\circ} \mathrm{C}$, respectively. The cell count of probiotics encapsulated with sodium alginate and carrageenan was $9.91 \log \mathrm{CFU} / \mathrm{mL}$ and $9.89 \log \mathrm{CFU} / \mathrm{mL}$ respectively at 0 day that decreased to $8.74 \log \mathrm{CFU} / \mathrm{mL}$ and $8.39 \log$
$\mathrm{CFU} / \mathrm{mL}$ respectively after $120 \mathrm{~d}$ at frozen storage (Afzaal et al. 2019). Based on this, it is necessary to carry out further research on CMF of OPL added with Na-alginate or other encapsulants to increase the storage time of probiotics that have viability above $10^{7} \mathrm{CFU} / \mathrm{g}$.

Probiotics consumed will pass through the stomach, which has a very acidic $\mathrm{pH}$, i.e., about 2 . Therefore, the probiotic must be resistant to acid to reach the small intestine and colon to perform its therapeutic function. The resistance of L. fermentum InaCC B1295 encapsulated using CMF hydrogel stored at various temperatures and storage time and treated at $\mathrm{pH} 2$ for $5 \mathrm{~h}$ is presented in Table 5 .

Table 4. Viability of Lactobacillus fermentum InaCC B1295 encapsulated using CMF hydrogel stored at various temperatures and times

\begin{tabular}{ccc}
\hline \multirow{2}{*}{ Storage time (d) } & \multicolumn{2}{c}{ Number of LAB (log CFU/mL) } \\
\cline { 2 - 3 } & $\begin{array}{c}\text { Room } \\
\text { temperature }\end{array}$ & $\begin{array}{c}\text { Refrigerated } \\
\text { temperature }\left(4^{\circ} \mathbf{C}\right)\end{array}$ \\
\hline 0 & ${ }^{\mathrm{x}} 10.09^{\mathrm{d}}$ & $\mathrm{y} 10.08^{\mathrm{e}}$ \\
7 & $\mathrm{x} 7.78^{\mathrm{c}}$ & $\mathrm{y} 8.27^{\mathrm{d}}$ \\
14 & $\mathrm{x} 7.37^{\mathrm{b}}$ & $\mathrm{y} 7.59^{\mathrm{b}}$ \\
21 & ${ }^{\mathrm{x}} 7.66^{\mathrm{c}}$ & $\mathrm{y} 7.98^{\mathrm{c}}$ \\
28 & ${ }^{\mathrm{x}} 7.49^{\mathrm{b}}$ & $\mathrm{y} 7.75^{\mathrm{c}}$ \\
35 & ${ }^{\mathrm{c}} 2.72^{\mathrm{a}}$ & $\mathrm{y} 5.36^{\mathrm{a}}$ \\
\hline
\end{tabular}

Note: ${ }^{a, b, c, d, e}$ Means in the same column with different superscript letters differ $(\mathrm{P}<0.05) .{ }^{\mathrm{x}, \mathrm{y}}$ Means in the same row with different superscript letters differ $(\mathrm{P}<0.05)$

Table 5. Number of Lactobacillus fermentum InaCC B1295 encapsulated using CMF hydrogel stored at various temperatures and times then treated at $\mathrm{pH} 2$

\begin{tabular}{ccc}
\hline \multirow{2}{*}{ Storage time (d) } & \multicolumn{2}{c}{ Number of LAB (log CFU/mL) } \\
\cline { 2 - 3 } & $\begin{array}{c}\text { Room } \\
\text { temperature }\end{array}$ & $\begin{array}{c}\text { Refrigerated } \\
\text { temperature (4 }\end{array}$ \\
\hline 0 & $\left.\times 9.86^{\mathrm{c}}\right)$ & $\times 9.87^{\mathrm{d}}$ \\
7 & $\times 9.39^{\mathrm{b}}$ & $\times 9.44^{\mathrm{c}}$ \\
14 & $\times 9.16^{\mathrm{ab}}$ & $\times 9.27^{\mathrm{bc}}$ \\
21 & $\times 9.12^{\mathrm{a}}$ & $\times 9.18^{\mathrm{ab}}$ \\
28 & $\times 9.11^{\mathrm{a}}$ & $\times 9.07^{\mathrm{ab}}$ \\
35 & $\times 8.94^{\mathrm{a}}$ & $\times 9.06^{\mathrm{a}}$ \\
\hline
\end{tabular}

Note: ${ }^{\mathrm{a}, \mathrm{b}, \mathrm{c}, \mathrm{d}}$ Means in the same column with different superscript letters differ $(\mathrm{P}<0.05) .{ }^{\mathrm{x}, \mathrm{y}}$ Means in the same row with different superscript letters differ $(\mathrm{P}<0.05)$ 
In this study, L. fermentum InaCC B1295 was treated at $\mathrm{pH} 2$ for $5 \mathrm{~h}$ to mimic gastric $\mathrm{pH}$ and the length of time food was in the stomach (Hill et al. 2014). The results showed that although this LAB has been stored at room and refrigerated temperatures for $35 \mathrm{~d}$, it could still be alive in acidic conditions with high numbers ranging from 8.94$9.87 \log \mathrm{CFU} / \mathrm{mL}$. This finding means that if this $\mathrm{LAB}$ is consumed, it will still have more than 7.0 $\log \mathrm{CFU} / \mathrm{mL}$ as a condition for performing its therapeutic function properly.

The high number of LAB treated with low $\mathrm{pH}$ was due to the CMF hydrogel from OPL still covering the LAB cells in acidic conditions. In addition, the reduction in cell number was minimal, with a range of 0.02 to $0.47 \mathrm{log}$ $\mathrm{CFU} / \mathrm{mL}$ stored at room and refrigerated temperatures (Table 6). The decrease in the number of LAB is minimal, indicating that the CMF hydrogel from OPL can maintain the survival of this LAB in very acidic conditions. This fact was probably due to the CMF hydrogel from OPL enveloping the $\mathrm{LAB}$ cells while they were treated at $\mathrm{pH} 2$ for $5 \mathrm{~h}$ at $37^{\circ} \mathrm{C}$. Thus, the cells of L. fermentum InaCC B1295 might not come in direct contact with $\mathrm{HCl}$, so that the decrease in the number of cells was less than $0.50 \mathrm{log}$ $\mathrm{CFU} / \mathrm{mL}$ at various storage times and storage temperatures. It is also the use of sodium alginate, which is widely used as an encapsulant because of its ability to form hydrogels with divalent cations in moderate conditions. The hydrogel that is formed maintains cells from various environmental conditions that are less favorable for LAB cells, for example, at very low pH (Simpson et al., 2004). Our results showed that $L$. fermentum InaCC B1295 showed a slight reduction in cell numbers than the findings of some researchers.

The encapsulated L. acidophilus and Bifidobacterium spp showed decreased cell count of about $0.5 \log \mathrm{CFU} / \mathrm{g}$ for 8 weeks, while free cells decreased by about 1 log CFU/g (Rizqiati et al. 2009). The results of other studies showed that the viability of co-encapsulated bacteria decreased by $1.62 \log \mathrm{CFU} / \mathrm{g}$, encapsulated cells decreased by $3.9 \log \mathrm{CFU} / \mathrm{g}$ and free cells decreased by $4.5 \mathrm{log}$ CFU/g after $3 \mathrm{~h}$ of incubation at pH 2 (Ngov et al. 2014). During the simulated gastrointestinal test, the encapsulated bacteria decreased only $3 \mathrm{log} \mathrm{CFU} / \mathrm{g}$, while for free cells decreased 7 log CFU/g (Afzaal et al. 2019). L. rhamnosus encapsulated with chitosan coating of microbeads and treated under acidic conditions for 40 to $120 \mathrm{~min}$ could maintain a decrease in cell numbers of only $0.94 \mathrm{log} \mathrm{CFU} / \mathrm{g}$ (Sohail et al. 2011).

Resistance to bile is one of the requirements for probiotics because probiotics must pass through the upper small intestine before performing their therapeutic function in the digestive tract (De Smet et al. 1995). Bile resistance of L. plantarum InaCC B1295 stored at various storage times and temperatures is presented in Table 7 . The results showed that even though this LAB was stored in a refrigerated room and temperature for $35 \mathrm{~d}$, it was still resistant to bile with a high number of din above $9.0 \mathrm{log}$ $\mathrm{CFU} / \mathrm{mL}$. Figures that have met the requirement of at least $7.0 \log \mathrm{CFU} / \mathrm{mL}$ as a requirement to carry out its therapeutic functions in the digestive tract. The high amount of LAB treated with low $\mathrm{pH}$ was due to the CMF hydrogel from OPL covering the LAB cells when treated with bile for $5 \mathrm{~h}$.
Bifidobacterium spp and L. acidophilus encapsulated with sodium caseinate, fructooligosaccharide, D-glucose, and mannitol have high bile resistance characterized by the amount of LAB between 8.3 and 9.2 log CFU/g at room temperature (Dianawati et al. 2016). Dikit et al. (2015) reported that the encapsulated L. plantarum D6SM3cells treated in simulated gastric juice was higher than free cells. The viability of the free cells and the encapsulated cell showed a gradual decrease during the storage period at $4{ }^{\circ} \mathrm{C}$. However, their viability drastically decreased at room temperature.

The high resistance to bile was indicated by reducing the small number of cells in the range of 0.10-0.75 log $\mathrm{CFU} / \mathrm{g}$ at various duration and storage temperatures (Table 8).

Table 6. The amount of reduction in Lactobacillus fermentum InaCC B1295 encapsulated with CMF hydrogel stored at various temperatures and time and treated with $\mathrm{pH} 2$.

\begin{tabular}{ccc}
\hline $\begin{array}{l}\text { Storage time } \\
\text { (d) }\end{array}$ & \multicolumn{2}{c}{ Number of LAB $(\log$ CFU/mL) } \\
\cline { 2 - 3 } & $\begin{array}{c}\text { Room } \\
\text { temperature }\end{array}$ & $\begin{array}{c}\text { Refrigerated } \\
\text { temperature }\left(4^{\circ} \mathbf{C}\right)\end{array}$ \\
\hline 0 & ${ }^{\mathrm{x}} 0.21^{\mathrm{ab}}$ & ${ }^{\mathrm{x}} 0.02^{\mathrm{ab}}$ \\
7 & ${ }^{\mathrm{x}} 0.18^{\mathrm{ab}}$ & ${ }^{\mathrm{x}} 0.17^{\mathrm{ab}}$ \\
14 & ${ }^{\mathrm{x}} 0.41^{\mathrm{b}}$ & ${ }^{\mathrm{x}} 0.38^{\mathrm{b}}$ \\
21 & ${ }^{\mathrm{x}} 0.47^{\mathrm{b}}$ & ${ }^{\mathrm{x}} 0.24^{\mathrm{ab}}$ \\
28 & ${ }^{\mathrm{x}} 0.20^{\mathrm{ab}}$ & ${ }^{\mathrm{x}} 0.12^{\mathrm{ab}}$ \\
35 & ${ }^{\mathrm{x}} 0.03^{\mathrm{ab}}$ & ${ }^{\mathrm{x}} 0.04^{\mathrm{a}}$ \\
\hline
\end{tabular}

Note: ${ }^{\mathrm{a}, \mathrm{b}}$ Means in the same column with different superscript letters differ $(\mathrm{P}<0.05)$. ${ }^{\mathrm{x}, \mathrm{y}}$ Means in the same row with different superscript letters differ $(\mathrm{P}<0.05)$

Table 7. Number of Lactobacillus fermentum InaCC B1295 encapsulated using CMF hydrogel stored at various temperatures and times then treated with bile

\begin{tabular}{ccc}
\hline \multirow{2}{*}{ Storage time (d) } & \multicolumn{2}{c}{ Number of LAB (log CFU/mL) } \\
\cline { 2 - 3 } & $\begin{array}{c}\text { Room } \\
\text { temperature }\end{array}$ & $\begin{array}{c}\text { Refrigerated } \\
\text { temperature }\left(4^{\circ} \mathbf{C}\right)\end{array}$ \\
\hline 0 & $\times 9.84^{\mathrm{b}}$ & $\times 9.93^{\mathrm{c}}$ \\
7 & $\times 9.69^{\mathrm{b}}$ & $\times 9.75^{\mathrm{ab}}$ \\
14 & $\times 9.65^{\mathrm{b}}$ & $\times 9.60^{\mathrm{b}}$ \\
21 & $\times 9.75^{\mathrm{b}}$ & $\times 9.81^{\mathrm{bc}}$ \\
28 & $\times 9.24^{\mathrm{a}}$ & $\times 9.55^{\mathrm{b}}$ \\
35 & ${ }^{\mathrm{a}} 9.24^{\mathrm{a}}$ & $\times 9.08^{\mathrm{a}}$ \\
\hline
\end{tabular}

Note: ${ }^{\mathrm{a}, \mathrm{b}, \mathrm{c}}$ Means in the same column with different superscript letters differ $(\mathrm{P}<0.05)$. ${ }^{\mathrm{x}, \mathrm{y}}$ Means in the same row with different superscript letters differ $(\mathrm{P}<0.05)$

Table 8. The amount of reduction in Lactobacillus fermentum InaCC B1295 encapsulated with CMF hydrogel stored at various temperatures and time and then treated with bile

\begin{tabular}{ccc}
\hline \multirow{2}{*}{ Storage time (d) } & \multicolumn{2}{c}{ Number of LAB $(\log$ CFU/mL) } \\
\cline { 2 - 3 } & $\begin{array}{c}\text { Room } \\
\text { temperature }\end{array}$ & $\begin{array}{c}\text { Refrigerated } \\
\text { temperature }\left(4^{\circ} \mathbf{C}\right)\end{array}$ \\
\hline 0 & ${ }^{\mathrm{x}} 0.32^{\mathrm{a}}$ & ${ }^{\mathrm{x}} 0.75^{\mathrm{a}}$ \\
7 & ${ }^{\mathrm{x}} 0.28^{\mathrm{a}}$ & ${ }^{\mathrm{x}} 0.33^{\mathrm{a}}$ \\
14 & ${ }^{\mathrm{x}} 0.19^{\mathrm{a}}$ & ${ }^{\mathrm{x}} 0.18^{\mathrm{a}}$ \\
21 & ${ }^{\mathrm{x}} 0.16^{\mathrm{a}}$ & ${ }^{\mathrm{x}} 0.22^{\mathrm{a}}$ \\
28 & ${ }^{\mathrm{x}} 0.16^{\mathrm{a}}$ & ${ }^{\mathrm{x}} 0.17^{\mathrm{b}}$ \\
35 & ${ }^{\mathrm{x}} 0.10^{\mathrm{a}}$ & ${ }^{\mathrm{a}} 0.12^{\mathrm{a}}$ \\
\hline
\end{tabular}

Note: ${ }^{\mathrm{a}, \mathrm{b}}$ Means in the same column with different superscript letters differ $(\mathrm{P}<0.05)$. ${ }^{\mathrm{x}, \mathrm{y}}$ Means in the same row with different superscript letters differ $(\mathrm{P}<0.05)$ 
Survival of L. fermentum InaCC B1295 against bile was very high, indicated by a minimal decrease in the amount of $\mathrm{LAB}$, which was less than $1 \log \mathrm{CFU} / \mathrm{mL}$. This fact shows that the CMF hydrogel from OPL was able to protect this LAB in bile. The protective mechanism may be due to the CMF hydrogel from OPL, which envelops the LAB cells to not come into direct contact with the bile. A similar mechanism also occurs in sodium alginate, which also forms hydrogels with divalent cations in moderate conditions. The hydrogel that is formed protects the cells from various environmental conditions that are less favorable for LAB cells, for example, in the bile, which is secreted into the upper part of the small intestine to emulsify fat (Tripathi and Giri 2014).

Our findings indicate that L. fermentum InaCC B1295 showed a slight reduction in cell numbers than the findings of other researchers. Eight species of Lactobacillus were exposed to ox gall, the viability of free cells was reduced by $6.51 \log \mathrm{CFU} / \mathrm{mL}$, while the encapsulated $\mathrm{LAB}$ only decreased by $3.36 \log$ CFU/mL (Ding and Shah, 2007). The encapsulated LC 1463 strain showed only a $1.4 \mathrm{log}$ $\mathrm{CFU} / \mathrm{mL}$ reduction after exposure to $1 \%$ bile salts for $3 \mathrm{~h}$. Under the same conditions, free cells decreased by 3.7-4.7 $\log \mathrm{CFU} / \mathrm{mL}$. The encapsulated LA 1338 strain only decreased by $2.2 \log \mathrm{CFU} / \mathrm{mL}$, while free cells decreased by around 4.75-4.84 $\log \mathrm{CFU} / \mathrm{mL}$ (Ngov et al. 2014). Survival of free cell of $L$. gasseri SBT0274 was stable for 7 $\mathrm{d}$ of storage at $4^{\circ} \mathrm{C}$ and decreased significantly after this period. On the other hand, the amount of free cell of $L$. gasseri SBT0270 decreased continuously through storage for $28 \mathrm{~d}$ at $4^{\circ} \mathrm{C}$ after exposure to bile salt (Usman and Hosono 1999). The survival rate of probiotics encapsulated in SA/SPI beads did not decrease after $6 \mathrm{~h}$ of incubation in bile salts 0.5 and $1.0 \%$ (Praepanitchai et al. 2019).

In conclusions, the main content of OPL was carbohydrates, especially fiber, and it also contained ash, protein, and fat in small amounts. Fiber from OPL is mainly composed of lignin followed by cellulose and hemicellulose. XRD analysis showed that the crystal index of cellulose from OPLwas $10.1 \%$. FTIR analysis showed that the most considerable absorption value which was the stretching vibrations of the -OH group ranging from 2919.17 to $2914.82 \mathrm{~cm}^{-1}$. CMF from OPL maintained the viability of L. fermentum InaCC B 1295 for up to $28 \mathrm{~d}$ of storage at room and refrigerated temperature. The survival of L. fermentum InaCC B1295 at low pH and presence of bile was very high, characterized by a decrease in the number of cells by less than $0.5 \log \mathrm{CFU} / \mathrm{mL}$ during storage of $35 \mathrm{~d}$ at room and refrigerated temperatures.

\section{ACKNOWLEDGEMENTS}

We would like to thank the Ministry for Education, Culture, Research and Technology of the Republic of Indonesia for the research grant.

\section{REFERENCES}

Abbasiliasi S, Tan JS, Tengku Ibrahim TA, Bashokouh F, Ramakrishnan NR, Mustafa S, Ariff AB. 2017. Fermentation factors influencing the production of bacteriocins by lactic acid bacteria: A review. RSC Adv 7: 29395-29420. DOI: 10.1039/c6ra24579j.

Abdullah N, Sulaim F. 2013. The Oil Palm Wastes in Malaysia. Biomass Now-Sustain Growth Use. DOI: 10.5772/55302

Abghari A, Sheikh-Zeinoddin M, Soleimanian-Zad S. 2011. Nonfermented ice cream as a carrier for Lactobacillus acidophilus and Lactobacillus rhamnosus. Intl J Food Sci Technol 46: 84-92. DOI: 10.1111/j.1365-2621.2010.02453.x.

Afzaal M, Saeed F, Arshad MU, et al. 2019. The effect of encapsulation on the stability of probiotic bacteria in ice cream and simulated gastrointestinal conditions. Probiotics Antimicrob Proteins 11: 13481354. DOI: $10.1007 / \mathrm{s} 12602-018-9485-9$.

Ayoub A, Sood M, Singh J, et al. 2019. Microencapsulation and its applications in food industry. J Pharmacogn Phytochem 8: 32-37.

Bilang M, Tahir M, Haedar D. 2018. Study on the encapsulation viability of probiotic cells (Lactobacillus plantarum and Streptococcus thermophilus) in ice cream. Canrea J Food Technol Nutr Culin J 4152. DOI: 10.20956/canrea.v1i1.21

Chinga-Carrasco G. 2011. Cellulose fibres, nanofibrils and microfibrils: The morphological sequence of MFC components from a plant physiology and fibre technology point of view. Nanoscale Res Lett 6 : 1-7. DOI: 10.1186/1556-276X-6-417.

Daryono, Alkas TR. 2017. Utilization of waste district and palm oil leaves. J Hutan Tropika 5: 188-195.

de la Cruz Pech-Canul A, Ortega D, García-Triana A, et al. 2020. A brief review of edible coating materials for the microencapsulation of probiotics. Coatings 10: 1-34. DOI: 10.3390/coatings10030197.

De Smet I, Van Hoorde L, Vande Woestyne M, et al. 1995. Significance of bile salt hydrolytic activities of lactobacilli. J Appl Bacteriol 79: 292-301. DOI: 10.1111/j.1365-2672.1995.tb03140.x.

Dianawati D, Mishra V, Shah NP. 2016. Viability, acid and bile tolerance of spray dried probiotic bacteria and some commercial probiotic supplement products kept at room temperature. J Food Sci 81: M1472-M1479. DOI: 10.1111/1750-3841.13313.

Dikit P, H-Kittikun A, Maneerat S. 2015. Survival of encapsulated potentially probiotic Lactobacillus plantarum D6SM3 with bioemulsifier derived from spent yeast in simulated gastrointestinal conditions. Songklanakarin J Sci Technol 37: 425-432.

Dungani R, Jawaid M, Khalil HPSA, Aprilia S. 2013. A review on quality enhancement of oil palm trunk. Bioresources 8 (2): 3136-3156.

Fahma F, Iwamoto S, Hori N, et al. 2010. Isolation, preparation, and characterization of nanofibers from oil palm empty-fruit-bunch (OPEFB). Cellulose 17: 977-985. DOI: 10.1007/s10570-010-9436-4.

Fung WY, Yuen KH, Liong MT. 2011. Agrowaste-based nanofibers as a probiotic encapsulant: Fabrication and characterization. J Agric Food Chem 59: 8140-8147. DOI: 10.1021/jf2009342.

Hill C, Guarner F, Reid G, et al. 2014. Expert consensus document: The international scientific association for probiotics and prebiotics consensus statement on the scope and appropriate use of the term probiotic. Nat Rev Gastroenterol Hepatol 11: 506-514. DOI: 10.1038/nrgastro.2014.66

Hossain MN, Ranadheera CS, Fang Z, Ajlouni S. 2021. Impact of encapsulating probiotics with cocoa powder on the viability of probiotics during chocolate processing, storage, and in vitro gastrointestinal digestion. J Food Sci. DOI: 10.1111/17503841.15695 .

Jung SJ, Kim SH, Chung IM. 2015. Comparison of lignin, cellulose, and hemicellulose contents for biofuels utilization among 4 types of lignocellulosic crops. Biomass Bioenerg 83: 322-327. DOI: 10.1016/j.biombioe.2015.10.007

Khalil HPSA, Fazita MRN, Bhat AH, et al. 2010. Development and material properties of new hybrid plywood from oil palm biomass. Mater Des 31: 417-424. DOI: 10.1016/j.matdes.2009.05.040

Lavoine N, Desloges I, Dufresne A, Bras J. 2012. Microfibrillated cellulose-Its barrier properties and applications in cellulosic materials: A review. Carbohydr Polym 90: 735-764. DOI: 10.1016/j.carbpol.2012.05.026.

Lestari FA. 2016. Production of cellulose nanofiber hydrogels from oil palm empty bunches. [Thesis]. Faculty of Agricultural Technology, Bogor Agricultural University, Bogor. [Indonesian] 
Muneer S, Kim EJ, Park JS, Lee JH. 2014. Influence of green, red and blue light emitting diodes on multiprotein complex proteins and photosynthetic activity under different light intensities in lettuce leaves (Lactuca sativa L.). Intl J Mol Sci 15: 4657-4670. DOI: 10.3390/ijms 15034657.

Ngov S, Sukboonyasatit D, Phaseepol T. 2014. Enhancement of probiotic survival in low ph and bile salt condition using alginate-Hi-maize starch encapsulation. KKU Res J 19: 141-147.

Nuraida L, Palupi NS, Bastomi RR, et al. 2012. Evaluation of probiotics properties of lactic acid bacteria isolated from breast milk and their potency as starter culture. Intl J Food Nutr Public Heal 5: 33-60.

Nurhaita and Ruswendi 2007. The effects of several methods of processing oil palm leaf waste on nutrient content and digestibility invitro. J Ilmu-Ilmu Pertanian Indonesia 2: 139-144.

Pato U, Johan VS, Raidinawan AR, et al. 2020. Viability and quality of fermented milk made using local and commercial starters during fermentation and cold storage. J Agric Sci Technol 22: 1473-1485.

Pato U. 2003. Bile and acid tolerance of lactic acid bacteria isolated from dadih and their antimutagenicity against mutagenic heated tauco. Asian-Aust J Anim Sci 16 (11): 1680-1685.

Praepanitchai OA, Noomhorm A, Anal AK, Potes ME. 2019. Survival and behavior of encapsulated probiotics (Lactobacillus plantarum) in calcium-alginate-soy protein isolate-based hydrogel beads in different processing conditions ( $\mathrm{pH}$ and temperature) and in pasteurized mango juice. Biomed Res Intl. DOI: 10.1155/2019/9768152.

Risnasari I, Febrianto F, Wistara NJ, Sadiyo S. 2012. Morphology of microfibrillated cellulose from primary sludge. Jurnal Ilmu dan Teknologi Kayu Tropis 11 (2): 177-183. DOI: 10.51850/jitkt.v11i2.96. [Indonesian]

Rizali A, Fahcrianto, Ansari MH, Wahdi A. 2018. Utilization of fresh waste and palm oil leaves through fermentation Trichoderma sp. as cut cow feed. EnviroScienteae 14: 1-7.

Rizqiati H, Nurhidayat N, Nurwitri CC. 2009. Probiotic microcapsule characteristics of Lactobacillus plantarum encapsulated with skim milk and arabic gum. J Indon Trop Anim Agric 34: 139-144.
Sarvari F, Mortazavian AM, Fazeli MR. 2014. Biochemical characteristics and viability of probiotic and yogurt bacteria in yogurt during the fermentation and refrigerated storage. Appl Food Biotechnol 1: 55-61. DOI: $10.22037 / \mathrm{afb} . v 111.7125$.

Shadle LJ, Berry DA, Syamlal M. 2002. Coal conversion processes, gasification. Kirk-Othmer Encyclopedia of Chemical Technology, $5^{\text {th }}$ ed. John Wiley \& Sons, New York. DOI: 10.1002/0471238961.0701190913010801.a01.pub2.

Sianturi AH. 2018. Analysis of Total Hardness and Alkalinity in Bore Well Clean Water using the Titrim Method at PT Sucofindo, North Sumatra Province. [Thesis]. Universitas Sumatera Utara, Medan. [Indonesian]

Sohail A, Turner MS, Coombes A, et al. 2011. Survivability of probiotics encapsulated in alginate gel microbeads using a novel impinging aerosols method. Intl $\mathrm{J}$ Food Microbiol 145: 162-168. DOI: 10.1016/j.ijfoodmicro.2010.12.007

Sun RC, Tomkinson J, Ma PL, Liang SF. 2000. Comparative study of hemicelluloses from rice straw by alkali and hydrogen peroxide treatments. Carbohydr Polym 42: 111-122. DOI: 10.1016/S01448617(99)00136-8

Tripathi MK, Giri SK. 2014. Probiotic functional foods: Survival of probiotics during processing and storage. J Funct Foods 9: 225-241. DOI: $10.1016 /$ j.jff.2014.04.030.

Usman, Hosono A. 1999. Viability of Lactobacillus gasseri and its cholesterol-binding and antimutagenic activities during subsequent refrigerated storage in nonfermented milk. J Dairy Sci 82: 2536-2542. DOI: $10.3168 /$ jds.S0022-0302(99)75507-4.

Yasim-Anuar TAT, Ariffin H, Hassan MA. 2018. Characterization of cellulose nanofiber from oil palm mesocarp fiber produced by ultrasonication. IOP Conf Ser Mater Sci Eng 368: 012033. DOI: 10.1088/1757-899X/368/1/012033.

Yasim-Anuar TAT, Ariffin H, Norrrahim MNF, Hassan MA. 2017. Factors affecting spinnability of oil palm mesocarp fiber cellulose solution for the production of microfiber. BioResources 12: 715-734. DOI: 10.15376/biores.12.1.715-734 